Economics Development Analysis Journal

\title{
Pengaruh Rata-Rata Lama Berpendidikan dan Pengeluaran Pemerintah Terhadap Penyerapan Tenaga Kerja
}

\section{Gambang Abdul Makna ${ }^{\bowtie}$}

Jurusan Ekonomi Pembangunan, Fakultas Ekonomi, Universitas Negeri Semarang

\section{Info Artikel \\ Abstrak}

\begin{abstract}
Tujuan dari penelitian ini adalah untuk mengetahui pengaruh rata-rata lama pendidikan dan pengeluaran pemerintah terhadap penyerapan tenaga kerja, apakah koefiseien negatif ataukah positif. Hasil dari penelitian ini adalah koefisien negatif dari rata-rata lama berpendidikan adalah 37,61 yang berarti jika rata-rata lama berpendidikan naik $1 \%$ maka penyerapan tenaga kerja turun 37,61. Koefisien positif dari pengeluaran pemerintah sektor pendidikan sebesar 9,48 yang berarti jika pengeluaran pemerintah sektor pendidikan naik $1 \%$ maka penyerapan tenaga kerja naik sebesar 9,48 . Koefisien positif dari pengeluaran pemerintah sektor kesehatan sebesar 1,81 yang berarti jika pengeluaran pemerintah sektor kesehatan naik sebesar $1 \%$ maka penyerapan tenaga kerja juga naik sebesar 1,81. Rata-rata lama berpendidikan. Pengeluaran pemerintah sektor pendidikan dan pengeluaran pemerintah sektor kesehatan secara bersama sama berpengaruh terhadap penyerapan tenaga kerja.
\end{abstract}

Sejarah Artikel:

Diterima Januari 2016

Disetujui Maret 2016

Dipublikasikan Mei 2016

Keywords:

Government spending

Education Sector, Education

Sector Government

expenditure, Average Length

educated, Manpower

Absorption.

\section{Abstract}

The purpose of this study is to determine the effect of the average length of education and government spending on employment, whether the coefficient negative or positive. Results from this study is the negative coefficient of the average length of education is -37.61 that means if the average length of education rose $1 \%$, the employment fell 37.61. Positive coefficient of government expenditures for education sector is 9.48, which means if the government education spending rose $1 \%$, the employment increased by 9.48. Positive coefficient of government spending health sector amounted to 1.81 which means that if the government health sector spending rose by $1 \%$ then employment also rose by 1.81. The average length of education. Government expenditure of education sector and the health sector of government spending with the same effect on employment

(C) 2016 Universitas Negeri Semarang

\footnotetext{
Alamat korespondensi:

Ruang Jurnal Gedung L FE UNNES, Sekaran Gunungpati

Semarang, 50229, Indonesia

E-mail: gambangabdulmakna@gmail.com
}

ISSN 2252-6765 


\section{PENDAHULUAN}

Sumber Daya Manusia adalah salah satu faktor yang dimiliki untuk memperoleh kesempatan dalam suatu pekerjaan, dimana beraneka ragam kualitas dan keterampilan yang dimilikinya, sehingga dalam hal ini bagaimana memperoleh Sumber Daya Manusia yang berkualitas dan mempunyai keterampilan serta daya saing tinggi. Dalam hubungannya dengan kualitas sumber daya manusia, pendidikan dianggap sebagai sarana untuk meningkatkan kualitas sumber daya manusia. Pendidikan yang baik diharapkan mampu memberikan sumber daya manusia yang baik pula. Salah satu masalah yang mendesak dari masyarakat modern adalah aksesibilitas dan kualitas pendidikan yang lebih tinggi untuk berbagai kelompok populasi (Gegel et al., 2015).

Tabel 1. Rata-rata lama Pendidikan di Pulau Jawa Tahun 2012

\begin{tabular}{clc}
\hline No & Provinsi & $\begin{array}{c}\text { Rata-rata lama } \\
\text { pendidikan } \\
\text { (Tahun) }\end{array}$ \\
\hline 1 & DKI Jakarta & 10,4 \\
2 & D.I Yogyakarta & 9,1 \\
3 & Banten & 8,3 \\
4 & Jawa Barat & 8,0 \\
5 & Jawa Timur & 7,5 \\
6 & Jawa Tengah & 7,4 \\
\hline
\end{tabular}

Sumber:BPS, rata-rata lama pendidikan 2012
Dari tabel di atas menunjukkan rata-rata lama berpendidikan di Pulau jawa dengan peringkat pertama yaitu Provinsi DKI Jakarta dan peringkat terakhir yaitu jawa Tengah. Kondisi ini tentu saja sangat memprihatinkan mengingat salah satu tolak ukur untuk mengetahui sejauh mana kondisi Sumber Daya Manusia yaitu rata-rata lama berpendidikan. Dalam konteks pengembangan sumber daya manusia, Soekidjo (2009:6) menjelaskan bahwa "pendidikan merupakan upaya untuk mengembangkan sumber daya manusia, terutama mengembangkan kemampuan intelektual dan kepribadian manusia".

Pembangunan manusia juga sangat diperlukan adanya peran pemerintah dalam melakukan kebijakan yang berkaitan dengan peningkatan kualitas pembangunan manusia. Dalam hal ini pemerintah harus mengalokasikan anggaran di sektor kesehatan dan pendidikan, mengingat kedua sektor tersebut juga berperan dalam mendukung keberhasilan pembangunan manusia. Dengan dasar temuan teoritis pada pengembangan modal manusia indeks pembangunan sumber daya manusia yang terdiri dari tiga sub-indeks: kemajuan sosial modal manusia, tingkat perkembangan inovasi modal manusia dan potensi pengembangan modal manusia telah diciptakan (Vaitkevicius et al.,2015). Berikut merupakan data alokasi pengeluaran pemerintah Kabupaten/Kota Provinsi Jawa Tengah untuk sektor pendidikan dan kesehatan: 
Tabel 2. Rata-rata Alokasi Pengeluaran Pemerintah Sektor Pendidikan Kabupaten/Kota di Jawa Tengah Tahun 2008-2012 (dalam rupiah)

\begin{tabular}{cccc}
\hline \multirow{2}{*}{ Tahun } & Total Pengeluaran & \multicolumn{2}{c}{ Rata-Rata } \\
& & Kabupaten & Kota \\
\hline $\mathbf{2 0 0 8}$ & 8.961 .163 .283 .228 & 275.751 .632 .184 & 163.632 .491 .650 \\
$\mathbf{2 0 0 9}$ & 10.824 .243 .207 .411 & 330.367 .341 .304 & 205.256 .051 .600 \\
$\mathbf{2 0 1 0}$ & 11.338 .509 .736 .544 & 348.256 .051 .576 & 206.514 .040 .576 \\
$\mathbf{2 0 1 1}$ & 12.601 .629 .149 .785 & 388.723 .171 .607 & 221.442 .862 .195 \\
$\mathbf{2 0 1 2}$ & 17.812 .355 .842 .000 & 553.382 .728 .034 & 294.042 .788 .167 \\
\hline
\end{tabular}

Sumber : Biro Keuangan Sekretaris Daerah Provinsi Jawa Tengah

Berdasarkan Tabel 2 menunjukkan total alokasi pengeluaran pemerintah untuk sektor pendidikan mengalami perkembangan yang positif, dimana alokasi pengeluaran sektor pendidikan selalu meningkat selama tahun 2008 sampai tahun 2012.

Tabel 3. Rata-Rata Alokasi Pengeluaran Pemerintah Sektor Kesehatan Kabupaten/Kota di Jawa Tengah Tahun 2008-2012 (dalam rupiah)

\begin{tabular}{cccc}
\hline \multirow{2}{*}{ Tahun } & Total Pengeluaran & \multicolumn{2}{c}{ Rata-Rata } \\
& & Kabupaten & Kota \\
\hline $\mathbf{2 0 0 8}$ & 2.224 .425 .955 .912 & 66.603 .199 .479 & 48.822 .195 .169 \\
$\mathbf{2 0 0 9}$ & 2.597 .736 .298 .829 & 77.203 .836 .838 & 57.804 .170 .266 \\
$\mathbf{2 0 1 0}$ & 2.689 .340 .174 .214 & 78.926 .987 .400 & 58.824 .408 .568 \\
$\mathbf{2 0 1 1}$ & 3.175 .699 .600 .264 & 93.920 .671 .050 & 75.333 .356 .637 \\
$\mathbf{2 0 1 2}$ & 3.778 .260 .334 .000 & 110.314 .347 .931 & 96.524 .040 .667 \\
\hline
\end{tabular}

Sumber : Biro Keuangan Sekretaris Daerah Provinsi Jawa Tengah

Berdasarkan Tabel 3 menunjukkan total alokasi pengeluaran pemerintah untuk sektor kesehatan mengalami perkembangan yang positif, dimana alokasi pengeluaran sektor kesehatan selalu meningkat selama tahun 2008 sampai tahun 2012. Keberhasilan pembangunan ekonomi suatu daerah dapat dilihat dari meningkatnya kualitas sumber daya manusia.
Oleh karena itu dibutuhkan keseriusan pemerintah dalam menangani masalah peningkatan pembangunan manusia di Jawa Tengah. Salah satu bukti keseriusan pemerintah untuk mendorong pembangunan di Jawa Tengah yaitu dengan melakukan pengeluaran pemerintah disektor pendidikan dan kesehatan yang bertujuan untuk meningkatkan kualitas 
sumber daya manusia yang ada, sehingga tolak ukur sumber daya manusia yang salah satunya adalah rata-rata lama berpendidikan akan meningkat. Kurang meratanya jumlah penyerapan tenaga kerja di Jawa Tengah dari tahun ke tahun dan masih rendahnya rata-rata lama berpendidikan merupakan suatu permasalahan yang ada.

Pengertian dari penyerapan itu sendiri diartikan cukup luas, menyerap tenaga kerja dalam maknanya menghimpun orang atau tenaga kerja di suatu lapangan usaha, untuk dapat sesuai dengan kebutuhan usaha itu sendiri. Menurut Kuncoro (2002:45) penyerapan tenaga kerja adalah banyaknya lapangan kerja yang sudah terisi dengan banyaknya jumlah penduduk yang bekerja. Penduduk yang bekerja terserap dan tersebar di berbagai sektor perekonomian. Terserapnya penduduk bekerja disebabkan oleh adanya permintaan akan tenaga kerja. Dalam ilmu ekonomi seperti kita ketahui faktor-faktor produksi yang terdiri dari: tanah, modal, tenaga kerja, skill. Salah satu faktor tersebut adalah tenaga kerja yang sesuai dengan keahlian dan ketrampilan yang dimiliki agar tenaga kerja dapat memperoleh suatu pekerjaan yang sesuai dengan keahlian dan ketrampilan tersebut. Oleh karena itu modal utama yang dibutuhkan adalah sumber daya manusia yang berkualitas.

Pertumbuhan tenaga kerja ditentukan oleh pertumbuhan penduduk di masa lampau, dimana penduduk merupakan sumber pokok bagi penawaran tenaga kerja. Besar kecilnya penawaran tenaga kerja tergantung pada jumlah penduduknya. Wilayah yang memiliki jumlah penduduk lebih banyak pasti memiliki jumlah angkatan kerja atau penawaran tenaga kerja yang lebih banyak daripada wilayah yang memiliki jumlah penduduk lebih sedikit. Besarnya penyediaan atau supply tenaga kerja dalam masyarakat adalah jumlah orang yang menawarkan jasanya untuk proses produksi. Diantara mereka sebagian sudah aktif dalam kegiatan yang menghasilkan barang dan jasa, mereka dinamakan golongan yang bekerja. Sebagian lain tergolong yang siap bekerja dan yang sedang berusaha mencari pekerjaan, mereka dinamakan pencari kerja. Dapat didefinisikan bahwa penawaran tenaga kerja mencakup semua orang yang mempunyai pekerjaan ditambah jumlah mereka yang secara aktif mencari pekerjaan.

Sumber daya manusia (SDM) merupakan salah satu faktor kunci dalam reformasi ekonomi, yakni bagaimana menciptakan SDM yang berkualitas dan memiliki keterampilan serta berdaya saing tinggi dalam persaingan global. Hal ini juga diungkapkan oleh Madura (2007:414), "Salah satu sumber daya yang berperan penting dalam perusahaan ialah sumber daya manusia, karena sumber daya manusia merupakan salah satu faktor yang menentukan apakah sebuah organisasi/perusahaan akan berhasil atau tidak". Pendapat lain menyatakan bahwa faktor SDM menjadi penting karena pada akhirnya keunggulan kompetitif sebuah negara akan ditentukan oleh kualitas SDM yang dimiliki negara itu.

Rata-rata lama berpendidikan mengindikasikan semakin tingginya pendidikan formal yang dicapai oleh masyarakat suatu daerah. Semakin tinggi rata-rata lama pendidikan berarti semakin tinggi jenjang pendidikan yang dijalani. Rata-rata lama berpendidikan yaitu rata-rata jumlah tahun yang dihabiskan oleh penduduk untuk menempuh jenjang pendidikan formal yang diikuti. Untuk meningkatkan rata-rata lama berpendidikan, pemerintah telah mencanangkan program wajib belajar 9 tahun atau pendidikan dasar hingga tingkat SLTP. Sistem pendidikan menjadi refleksi dari kualitas lulusan dan kesiapan untuk keterampilan yang dibutuhkan (Soukalova \& Gottlichova, 2015). Rata-rata lama pendidikan merupakan indikator tingkat pendidikan di suatu daerah. Pendidikan merupakan salah satu bentuk modal manusia (human capital) yang menunjukkan kualitas Sumber Daya Manusia (SDM).

Pendidikan merupakan suatu bentuk investasi sumber daya manusia. Tingkat pendidikan juga bepengaruh terhadap kinerja atau penyerapan tenaga kerja karena pendidikan merupakan salah satu komponen utama dalam meningkatkan pengetahuan, pengalaman dan 
keterampilan dalam meningkatkan kualitas pencari kerja. Pelayanan pendidikan masyarakat yang paling elementer adalah pendidikan dasar, yang oleh pemerintah diterjemahkan dalam program Wajib Belajar Sembilan Tahun. Pemerintah hendaknya menjamin bahwa semua anak dapat bersekolah, sehingga diperlukan alokasi anggaran pendidikan yang besar. Dalam pemenuhan anggaran tersebut amanat amandemen UUD 1945 telah mensyaratkan alokasi anggaran pendidikan minimal 20 persen dari total anggaran. Kaitannya dengan tenaga kerja, ketika pendidikan dari tenaga kerja semakin tinggi maka kesempatan kerja semakin besar dan penyerapan tenaga kerja di suatu wilayah dapat meningkat.

Kesehatan merupakan salah satu kebutuhan dasar masyarakat, oleh karena itu kesehatan adalah hak bagi setiap warga yang dilindungi oleh undang-undang dasar. Perbaikan pelayanan kesehatan pada dasarnya merupakan suatu investasi sumber daya manusia untuk mencapai masyarakat yang sejahtera (welfare society). Adanya pengeluaran pemerintah di sektor kesehatan sangat diperlukan guna meningkatkan kualitas sumber daya manusia. Pengaruh perbaikan kesehatan meningkatkan partisipati tenaga kerja selanjutnya memperbaiki pendidikan dan kemudian akan menyumbang pada peningkatan penyerapan tenaga kerja yang terampil. Oleh karena kesehatan merupakan faktor utama kesejahteraan masyarakat yang hendak diwujudkan pemerintah, maka kesehatan harus menjadi perhatian utama pemerintah sebagai penyelenggara pelayanan publik. Pemerintah harus mampu menjamin masyarakat yang sehat dengan memberikan pelayanan kesehatan secara adil, merata, memadai, terjangkau, dan berkualitas.

\section{METODE PENELITIAN}

Data yang digunakan dalam penelitian ini merupakan data sekunder yang bersumber pada laporan Badan Pusat Statistik (BPS) dan Biro Keuangan Sekretaris Daerah Provinsi Jawa Tengah tahun 2008 sampai dengan tahun 2012, data yang diteliti adalah data penyerapan tenaga kerja, rata-rata lama berpendidikan, pengeluaran pemerintah sektor pendidikan, dan pengeluaran pemerintah sektor kesehatan kabupaten/kota di Jawa Tengah. Jenis data yang digunakan adalah data panel yaitu gabungan time series dan cross section. Data time series periode tahun 2008-2012 sedangkan data cross section adalah 35 kabupaten/kota di Jawa Tengah.

Dalam penelitian ini, sesuai dengan bentuk pendekatan penelitian kuantitatif data yang digunakan adalah data sekunder. Data sekunder dalam penelitian ini diperoleh dari lembaga/instansi yang terkait dalam penelitian ini antara lain BPS provinsi Jawa Tengah, Sekretaris Daerah Biro Keuangan Provinsi Jawa Tengah, Direktorat Jendral Perimbangan Keuangan dengan mengambil seluruh populasi yaitu sebanyak 35 kabupaten/kota di Provinsi Jawa Tengah.

Menurut Gujarati (2010:237), data panel (pooled data) atau yang disebut juga data longitudinal merupakan gabungan antara data cross section dan data time series. Data cross section adalah data yang dikumpulkan dalam satu waktu terhadap banyak individu, sedangkan data time series merupakan data yang dikumpulkan dari waktu ke waktu terhadap suatu individu. Menurut Ajija, dkk (2011:51) ada tiga metode yang digunakan untuk mengestimasi data panel yaitu: Model Pooled Least Square (Comon Effect), model ini dikenal dengan estimasi Comon Effect yaitu teknik regresi yang paling sederhana untuk mengestimasi data panel dengan cara hanya mengkombinasikan data time series dan cross section. Model Pendekatan Efek Tetap (Fixed Effect), Pada metode Fixed Effect estimasi dapat dilakukan dengan tanpa pembobot (no weight) atau Least Square Dummy Variable (LSDV) dan dengan pembobot (cross section weight) atau General Least Square (GLS). Tujuan dilakukannya pembobotan adalah untuk mengurangi heterogenitas antar unit cross section (Gujarati, 2010:472). Model Pendekatan Efek Acak (Random Effect), Dalam model efek acak, parameter-parameter yang berbeda antar daerah maupun antar waktu dimasukan ke dalam error. Karena hal inilah, model efek acak juga disebut model komponen error (error component model). 


\section{Spesifikasi Model Regresi}

Secara ekonometrika hubungan antara rata-rata lama berpendidikan, pengeluaran pemerintah sektor pendidikan dan pengeluaran sektor kesehatan terhadap penyerapan tenaga kerja kabupaten/kota di Provinsi Jawa Tengah dapat dianalisis dengan menggunakan persamaan sebagai berikut ini:

$$
Y_{\text {it }}=\alpha_{i}+\beta_{1} X_{1 i t}+\beta_{2} X_{2 i t}+\beta_{3} X_{3 i t}+e_{i t}
$$

Keerangan :

$\mathrm{Y}_{\mathrm{it}} \quad=$ Penyerapan tenaga kerja (orang/unit)

$\mathrm{X}_{1} \quad$ = Rata-rata lama berpendidikan (tahun)

$\mathrm{X}_{2} \quad=$ Pengeluaran pemerintah sektor pendidikan (milyar rupiah)

$\mathrm{X}_{3} \quad=$ Pengeluaran pemerintah sektor kesehatan (milyar rupiah),

$\mathrm{Ai} \quad=$ Konstanta

$\beta_{1}$ dan $\beta_{2}=$ Koefisien regresi untuk masingmasing variabel

$e \quad=$ Residual

\section{HASIL DAN PEMBAHASAN}

\section{Penaksiran Model}

Redundant Fixed Effect - Likelihood Ratio, Pengujian yang dapat dilakukan untuk memilih model terbaik antara model common effect model dengan fixed effect model. Berdasarkan hasil pengujian diketahui bahwa nilai probabilitas Cross-Section Chi-Square sebesar 0,0000 dan signifikan terhadap alpha 5\% sehingga dapat diputuskan bahwa model yang dipilih menggunakan fixed effect.

Correlated Fixed Effect - Hausman Test, Pengujian yang dapat dilakukan untuk memilih model yang terbaik antara fixed effect model dengan random effect model. Berdasarkan hasil pengujian diketahui bahwa probabilitas Crosssection random sebesar 0,0000 dan signifikan dengan alpha $5 \%$ sehingga dapat diputuskan model yang dipilih adalah dengan menggunakan fixed effect.

Selain serangkaian uji tersebut, pemilihan model juga dilakukan dengan melihat uji goodness of fitnya. Uji goodness of fit selengkapnya disajikan dalam tabel berikut.

Tabel 4. Hasil Estimasi Pengaruh Pengeluaran Pemerintah Terhadap Pertumbuhan Ekonomi

Kabupaten/Kota Di Jawa Tengah

\begin{tabular}{|c|c|c|c|}
\hline \multirow{2}{*}{$\begin{array}{c}\text { Variabel Dependen } \\
\text { (TN) }\end{array}$} & \multicolumn{3}{|c|}{ Model } \\
\hline & Common Effect & Fixed Effect & Random Effect \\
\hline KONSTANTA & 589587,5 & 244261,0 & 464820,5 \\
\hline Standar error & 66027,90 & 49952,97 & 58282,64 \\
\hline Probabilitas & $(0,0000)^{* *}$ & $(0,0000)$ & $(0,0000)$ \\
\hline LOGRB & $-59019,59$ & $-37167,43$ & $-52856,48$ \\
\hline Standar error & 7765,861 & 4537,266 & 6258,546 \\
\hline Probabilitas & $(0,0000)^{* *}$ & $(0,0000)^{* *}$ & $(0,0000)^{* *}$ \\
\hline LOGPPP & $6,11 \mathrm{E}-07$ & $9,48 \mathrm{E}-07$ & $7,29 \mathrm{E}-07$ \\
\hline Standar error & $8,22 \mathrm{E}-08$ & $6,15 \mathrm{E}-08$ & $7,03 \mathrm{E}-08$ \\
\hline Probabilitas & $(0,0000)^{* *}$ & $(0,0000)^{* *}$ & $(0,0000)^{* *}$ \\
\hline LOGPPS & $9,76 \mathrm{E}-07$ & 1,81E-06 & $1,44 \mathrm{E}-06$ \\
\hline Standar error & $4,28 \mathrm{E}-07$ & $6,15 \mathrm{E}-08$ & $3,46 \mathrm{E}-07$ \\
\hline Probabilitas & $(0,0239)^{* *}$ & $(0,0000)^{\star *}$ & $(0,0000)^{* *}$ \\
\hline $\mathrm{R}^{2}$ & 0,574460 & 0,898430 & 0,670847 \\
\hline $\mathrm{F}_{\text {Statistic }}$ & 76,94751 & 32,75189 & 116,1718 \\
\hline Probabilitas & $(0,000000)^{* *}$ & $(0,000000)^{\star *}$ & $(0,000000)^{* *}$ \\
\hline
\end{tabular}

** : signifikan pada $\alpha=5 \%$ 
Berdasarkan Uji Spesifikasi Model yang telah dilakukan serta dari perbandingan goodness of fit-nya, maka model regresi yang digunakan dalam mengestimasikan pengaruh rata-rata lama berpendidikan $(\log R B)$, pengeluaran pemerintah sektor pendidikan (logPPP) dan pengeluaran pemerintah sektor pendidikan (logPPS) terhadap penyerapan tenaga kerja (TN) di Jawa Tengah adalah fixed effect model.

Model regresi pengaruh rata-rata lama berpendidikan, pengeluaran pemerintah sektor pendidikan dan pengeluaran pemerintah sektor kesehatan terhadap penyerapan tenaga kerja di Kabupaten/Kota Provinsi Jawa Tengah tahun 2008 sampai dengan tahun 2012 dengan model fixed effect dan model GLS, diperoleh nilai koefisien regresi untuk setiap variable penelitian dengan persamaan sebagai berikut:

$$
\begin{aligned}
\mathrm{Y}_{\mathrm{it}} \quad & \alpha_{\mathrm{i}}+\beta_{1} \mathrm{X}_{1 \mathrm{it}}+\beta_{2} \mathrm{X}_{2 \mathrm{it}}+\beta_{3} \mathrm{X}_{3 \mathrm{it}}+e_{\mathrm{it}} \ldots \ldots \text { (2) } \\
\mathrm{Y}_{\mathrm{it}} \quad= & 2444261,0-37617,43 \mathrm{X}_{\mathrm{lit}}+9,48 \mathrm{E} 07 \\
& \mathrm{X}_{2 \mathrm{it}}+2,87 \mathrm{E}-07 \mathrm{X}_{3 \mathrm{it}} \ldots \ldots \ldots \ldots \ldots \ldots .(3)
\end{aligned}
$$

Std Error $(49952,97) \quad(4537,266)$

$$
(6,15 \mathrm{E}-08) \quad(1,81 \mathrm{E}-06)
$$

$$
\begin{aligned}
& \text { Sig } \quad(0,0000) \quad(0,0000) \\
& (0,000) \quad(0,0000)
\end{aligned}
$$

\section{Pengaruh Rata-rata Lama Berpendidikan} Terhadap Penyerapan Tenaga Kerja

Berdasarkan hasil analisis dapat dijelaskan bahwa variabel rata-rata lama berpendidikan berpengaruh negatif dan signifikan dengan koefisien negative sebesar 37,61 terhadap penyerapan tenaga kerja kabupaten/kota Provinsi Jawa Tengah tahun 2008 sampai dengan tahun 2012. Hal ini menunjukkan bahwa apabila tingkat rata-rata lama berpendidikan mengalami peningkatan sebesar $1 \%$, maka penyerapan tenaga kerja di kabupaten/kota Provinsi Jawa Tengah akan menurun sebesar $37,61 \%$. Bisa dijelaskan bahwa dengan rata-rata lama berpendidikan yang rendah akan dapat mempengaruhi jumlah penyerapan tenga kerja di suatu lapangan pekerjaan.

Hasil penelitian ini menunjukkan bahwa rata-rata lama berpendidikan berkaitan dengan penyerapan tenaga kerja. Dalam hal ini berkaitan dengan jumlah ketersediaan lapangan pekerjaan yang tidak sesuai, sehingga peneliti berasumsi bahwa ketidaksesuaian antara lapangan pekerjaan dengan pendidikan terakhir yang diselesaikan oleh pencari kerja menyebabkan tingkat hubungan rata-rata lama berpendidikan dengan penyerapan tenaga kerja berpengaruh negatif.

\section{Pengaruh Pengeluaran Pemerintah Sektor Pendidikan Terhadap Penyerapan Tenaga Kerja}

Berdasarkan hasil analisis dapat dijelaskan bahwa variabel pengeluaran pemerintah sektor pendidikan berpengaruh positif dan signifikan dengan koefisien positif sebesar 9,48 terhadap penyerapan tenaga kerja di Kabupaten/kota Provinsi Jawa Tengah tahun 2008 sampai dengan tahun 2012. Hal ini menunjukkan bahwa apabila tingkat pengeluaran pemerintah sektor pendidikan mengalami kenaikan sebesar 1\%, maka akan meningkatkan penyerapan tenaga kerja di kabupaten/kota Provinsi Jawa Tengah sebesar $9,48 \%$. Hasil ini sesuai dengan hipotesis yang menyatakan ada pengaruh pengeluaran pemerintah sektor pendidikan terhadap penyerapan tenaga kerja di Jawa Tengah tahun 2008 sampai dengan 2012.

Pengeluaran pemerintah di sektor pendidikan menunjukkan hubungan yang positif terhadap penyerapan tenaga kerja, hal ini dapat diartikan bahwa pengeluaran pemerintah untuk sektor pendidikan sangat berperan dalam meningkatkan kebutuhan masyarakat akan pendidikan. Dengan adanya pengeluaran pemerintah di sektor pendidikan akan memberikan kemudahan kepada masyarakat untuk dapat mengakses pendidikan secara mudah, mengingat bahwa sektor pendidikan merupakan faktor yang mendukung untuk memperoleh suatu pekerjaan. 
Alokasi pengeluaran pemerintah di sektor pendidikan merupakan investasi untuk meningkatkan produktivitas masyarakat yang ada dan membenahi kualitas sumber daya manusia, sehingga dengan adanya alokasi pengeluaran pemerintah di sektor pendidikan tidak hanya menambah pengetahuan akan tetapi juga meningkatkan keterampilan kerja sehingga para pencari kerja dapat memperoleh pekerjaan yang layak.

Pengaruh Pengeluaran Pemerintah Sektor Kesehatan Terhadap Penyerapan Tenaga Kerja Berdasarkan hasil analisis dapat dijelaskan bahwa variabel pengeluaran pemerintah sektor kesehatan berpengaruh positif dan signifikan dengan koefisien 1,81 terhadap penyerapan tenaga kerja di Kabupaten/kota Provinsi Jawa Tengah tahun 2008 sampai dengan tahun 2012. Hal ini menunjukkan bahwa apabila tingkat pengeluaran pemerintah sektor kesehatan mengalami kenaikan sebesar $1 \%$, maka akan meningkatkan penyerapan tenaga kerja di kabupaten/kota Provinsi Jawa Tengah sebesar $1,81 \%$.

Pengeluaran pemerintah di sektor kesehatan menunjukkan hubungan yang positif terhadap penyerapan tenaga kerja, hal ini dapat diartikan bahwa pengeluaran pemerintah untuk sektor kesehatan sangat berperan dalam meningkatkan kebutuhan masyarakat akan kesehatan. Dengan adanya pengeluaran pemerintah di sektor kesehatan akan memberikan kemudahan kepada masyarakat untuk dapat mengakses kesehatan secara mudah.

Kesehatan adalah hal yang sangat penting bagi kebutuhan dasar manusia. Kesehatan merupakan hak bagi setiap warga, oleh karena itu pentingnya perbaikan gizi dan pelayanan kesehatan. Adanya perbaikan di bidang kesehatan merupakan bentuk investasi, adanya investasi di sektor kesehatan sangat diperlukan guna meningkatkan kualitas sumber daya manusia. Pengaruh perbaikan kesehatan dapat meningkatkan partisipati tenaga kerja untuk memperoleh pekerjaan yang layak.

Pengaruh Rata-rata lama Berpendidikan, Pengeluaran Pemerintah Sektor Pendidikan dan Pengeluaran Pemerintah Sektor Kesehatan
Terhadap Penyerapan Tenaga Kerja, berdasarkan hasil regresi di atas variabel rata-rata lama berpendidikan, pengeluaran pemerintah sektor pendidikan dan pengeluaran pemerintah sektor kesehatan berpengaruh secara bersamasama terhadap penyerapan tenaga kerja kabupaten/kota di Jawa Tengah tahun 2008 sampai 2012. Hal ini dibuktikan dengan probabilitas yang ditunjukkan pada tabel 4.1 dengan fixed effect model diperoleh nilai $\mathrm{F}_{\text {hitung }}$ sebesar 32,75 dengan probabilitas 0,000000. Sementara itu dengan nilai $F_{\text {tabel }}$ sebesar 2,66 maka $\mathrm{F}_{\text {hitung }}>\mathrm{F}_{\text {tabel. }}$. Dengan demikian dapat disimpulkan bahwa hasil ini sesuai dengan hipotesis penelitian.

Adanya rata-rata lama pendidikan dan pengeluaran pemerintah berkaitan erat dengan penyerapan tenaga kerja. Jumlah pengeluaran pemerintah baik di sektor pendidikan maupun di sektor kesehatan akan meningkatkan kualitas sumber daya manusia yang ada dan selanjutnya akan meningkatkan partisipasi penyerapan tenaga kerja. Dengan adanya pengeluaran pemerintah sektor pendidikan yang semakin meningkat akan mampu memberikan pengaruh yang besar terhadap kualitas pendidikan yang dibutuhkan untuk memperoleh suatu pekerjaan. Di sisi lain mengenai pengeluaran pemerintah sektor kesehatan juga akan meningkatkan partisipasi penyerapan tenaga kerja.

\section{SIMPULAN}

Berdasarkan hasil penelitian dan pembasan rata-rata lama berpendidikan mempunyai pengaruh negatif dan signifikan terhadap penyerapan tenaga kerja, pengeluaran pemerintah sektor pendidikan mempunyai pengaruh positif dan signifikan terhadap penyerapan tenaga kerja, pengeluaran pemerintah sektor kesehatan mempunyai pengaruh positif dan signifikan terhadap penyerapan tenaga kerja kemudian rata-rata lama berpendidikan, pengeluaran pemerintah sektor pendidikan dan pengeluaran sektor kesehatan secara bersama-sama berpengaruh terhadap penyerapan tenaga kerja di Kabupaten/Kota Provinsi Jawa Tengah. 
Sebaiknya, Pemerintah Kabupaten/Kota Provinsi Jawa Tengah disarankan memberikan perhatian kepada kabupaten/kota yang masih memiliki tingkat pendidikan yang rendah. Kabupaten Brebes, kabupaten Banjarnegara dan kabupaten Wonosobo memiliki tingkat pendidikan yang rendah dengan rata-rata tingkat pendidikan masing-masing 5,7 tahun, 6,1 tahun dan 6,3 tahun. Selanjutnya pemerintah sebagai pengambil kebijakan dalam hal pengalokasian dan penggunaan anggaran untuk penyedian kebutuhan publik dalam hal ini berkaitan dengan pendidikan harus lebih efektif, efisien dan tepat sasaran. Perlu adanya koordinasi di masingmasing Kabupaten/Kota Provinsi Jawa Tengah terkait dengan pemberdayaan tenaga kerja. Hal ini ditujukan utuk mewujudkan kualitas sumber daya manusia sesuai dengan potensi di Kabupaten/Kota Provinsi Jawa Tengah. Sehingga dapat melahirkan tenaga kerja dengan mindset yang lebih luas terhadap pilihan lapangan pekerjaan.

\section{DAFTAR PUSTAKA}

Ajija, Shochrul R,dkk. 2011. Cara Cerdas Menguasai Eviews. Jakarta: Salemba Empat.

Anggaryani, Putri. 2013. Pengaruh Tenaga Kerja Dan Investasi Sumber Daya Manusia Terhadap Pertumbuhan Ekonomi Indonesia Periode 1980-2012. Jurnal Ilmiah. Malang : Fakultas Ekonomi Dan Bisnis Universitas Brawijaya.

Badan Pusat Statistik Provinsi Jawa Tengah. 2008. Keadaaan Angkatan Kerja

Semarang: Badan Pusat Statistik Provinsi Jawa Tengah.

2009.

Keadaaan Angkatan Kerja. Semarang: Badan Pusat Statistik Provinsi Jawa Tengah.

2010

Keadaaan Angkatan Kerja. 2009.

Semarang: Badan Pusat Statistik Provinsi Jawa Tengah.

2011.

Keadaaan Angkatan Kerja Jawa Tengah 2010. Semarang: Badan Pusat Statistik Provinsi Jawa Tengah.

Keadaaan Angkatan Kerja Jawa Tengah 2011
Semarang: Badan Pusat Statistik Provinsi Jawa Tengah.

Badan Pusat Statistik Provinsi Jawa Tengah. 2008. Penyerapan Tenaga Kerja Jawa Tengah 2007. Semarang: Badan Pusat Statistik Provinsi Jawa Tengah

Penyerapan Tenaga Kerja Jawa Tengah 2008. Semarang: Badan Pusat Statistik Provinsi Jawa Tengah.

2010.

Penyerapan Tenaga Kerja.

Badan Pusat Statistik Provinsi Jawa Tengah. 2009. Semarang : Badan Pusat Statistika Provinsi Jawa Tengah

2011.

Penyerapan Tenaga Kerja Jawa Tengah 2010. Semarang: Badan Pusat Statistik Provinsi Jawa Tengah.

2012.

Penyerapan Tenaga Kerja Jawa Tengah 2011. Semarang: Badan Pusat Statistik Provinsi Jawa Tengah.

Badan Pusat Statistik Provinsi Jawa Tengah 2010. Indeks Pembangunan Manusia 2010. Semarang: Badan Pusat Statistik Provinsi Jawa Tengah.

Baeti, N. (2013). Pengaruh Pengangguran, Pertumbuhan Ekonomi, Dan Pengeluaran Pemerintah Terhadap Pembangunan Manusia Kabupaten/Kota Di Provinsi Jawa Tengah Tahun 2007-2011. Economics Development Analysis Journal, 2(3).

Bidang Ketenagakerjaan dan Ketransmigrasian Tentang Rencana pembangunan Jangka Panjang 2010-2025. 2012. Jakarta.

Biro Keuangan Sekretaris Daerah Provinsi Jawa Tengah. Alokasi Pengeluaran Pemerintah Sektor Kesehatan Kabupaten/Kota Di Jawa Tengah, Tahun 2008-2012.

Alokasi Pengeluaran Pemerintah Sektor Pendidikan Kabupaten/Kota Di Jawa Tengah, Tahun 2008-2012.

Departemen Perdagangan Republik Indonesia Tentang Menuju ASEAN Economic Community 2015. Jakarta.

Dwi Atmanti, Hastarini. 2005. "Investasi Sumber Daya Manusia Melalui Pendidikan". Dalam Dinamika Pembangunan Vol. 2, No. 2. Hal. 30-39. 2005. Jakarta. 
Gegel, L., Labedeva, I. \& Frolova, Y., 2015. Social Inequality In Modern Higher Education. Procedia-Social and Behavioral Sciences, 214, pp.368-74

Gujarati, D.N. dan D.C. Porter. 2010. Dasar-Dasar Ekonometrika, Edisi 5. Jakarta: Salemba Empat

2012. Dasar-Dasar

Ekonometrika, Edisi 5. Jakarta: Salemba Empat.

Istijanto. 2008. Riset Sumber Daya Manusia: Cara Praktis Mendeteksi Dimensi-Dimensi Kerja Karyawan. Jakarta: PT Gramedia Pustaka Utama.

Kuncoro. 2002. Upah Sistem Bagi Hasil dan Penyerapan Tenaga Kerja. Jurnal Ekonomi Pembangunan,Vol 7, Nomor 1 hal : 45-54.

Madura, J. 2007. Pengantar Bisnis. Jakarta: Salemba Empat.

Maulana, R. (2015). Pengaruh Human Capital Terhadap Pertumbuhan Ekonomi Regional Di Provinsi Jawa Tengah Tahun 2008-2012. Economics Development Analysis Journal, 4(2).

Mirza, D. (2012). Pengaruh Kemiskinan, Pertumbuhan Ekonomi, Dan Belanja Modal Terhadap Indeks Pembangunan Manusia Di Jawa Tengah Tahun 2006-2009. Economics Development Analysis Journal, 1(2).

Notoatmodjo, Soekidjo. 2009. Pengembangan Sumber Daya Manusia. Jakarta: Rineka Cipta.

Prastowo, Andi. 2010. Menguasai Teknik - Teknik Koleksi Data Penelitian Kualitatif. Yogyakarta: Diva Press.

Rahayuningsih, Idha, Nurul Hidayati Dan Isa Wahyudi. 2009. "Analisis Indeks Pembangunan Manusia (IPM) Dan Dampaknya Pada Peningkatan Pendidikan Kesehatan Dan Ekonomi DI Kabupaten Gresik". Jurnal Logos. Vol. 6 No. 2 Januari 2009. Hal 256-274.

Rianse, Usman dan Abdi. 2008. Metodologi Penelitian Soaial dan Ekonomi: Teori dan Aplikasi. Bandung: Alfabeta.

Sarwoko. 2005. Dasar-Dasar Ekonometrika. Yogyakarta: Andi Offset.

Simanjuntak Payaman J. 1998. Pengantar Ekonomi Sumber Daya Manusia, Edisi Kedua. Jakarta: Universitas Indonesia.

Situs Resmi Pemerintah Bekasi. 2012. Mengenal Indeks Pembangunan Manusia. http://www.bekasikota.go.id/read/6634/men genal-indeks-pembangunan-manusia. Agustus.2013).
Sugiyono. 2008. Metode Penelitian Kuantitatif dan Kualitatif dan R\&D. Bandung: Alfabeta.

Sugiyono. 2011. Metode Penelitian Kuantitatif, Kualitatif dan $R \& D$. Bandung: Alfabeta.

Suparno, E. 2009. Natural Manpower Strategi. Jakarta: PT Gramedia.

Soukalova, R. \& Gottlichova, M., 2015. The Impact Of Effective Process Of Higher Education On The Quality Of Human Resources In The Czech Republic. Procedia Social and Behavioral Sciences, 174, pp.3715-23.

Organisasi Perburuan Internasional Tentang Tren Ketenagakerjaan dan Sosial DI Indonesia 2008. 2008. Jakarta.

$\mathrm{Qu}$, Yue dan Cai, Fang. “Understanding China's Workforce Competitiveness" Journal of Chinese Human Resource Management . Chinese Academy of Social Sciences, Beijing, China.

Todaro, Michael P. 2000. Pembangunan Ekonomi. Jakarta : Erlangga.

Todaro, Michael P dan Smith S.C. 2006. Pembangunan Ekonomi. Jakarta: Erlangga.

Undang - Undang Republik Indonesia Nomor 13 Tahun 2003 Tentang Ketenagakerjaan.

Vaitkevicius, , Ciutiene, R., Meiliene, E. \& Savanaviciene, A., 2015. Typology Of Human Capital Development In Eu Countries. Procedia Economics and Finance, 23, pp.1641-48.

Yudi, Meiditya Prabaningtyas. 2015. "Pengaruh Upah, Modal, Jumlah Unit Usaha, Jumlah Produksi Terhadap Penyerapan Tenaga Kerja Industri Kecil Tahu Bakso Dengan Menggunakan Path Analysis”. Jurnal Ilmiah. Semarang : Jurusan Ekonomi Pembangunan, Fakultas Ekonomi Universitas Negeri Semarang. 